\title{
Artificial lakes delay the migration of brown trout Salmo trutta smolts: a comparison of migratory behaviour in a stream and through an artificial lake
}

\author{
Schwinn, Michael; Baktoft, Henrik; Aarestrup, Kim; Koed, Anders
}

Published in:

Journal of Fish Biology

Link to article, DOI:

$10.1111 / \mathrm{jfb} .13950$

Publication date:

2019

Document Version

Peer reviewed version

Link back to DTU Orbit

Citation (APA):

Schwinn, M., Baktoft, H., Aarestrup, K., \& Koed, A. (2019). Artificial lakes delay the migration of brown trout Salmo trutta smolts: a comparison of migratory behaviour in a stream and through an artificial lake. Journal of Fish Biology, 94(5), 745-751. https://doi.org/10.1111/jfb.13950

\section{General rights}

Copyright and moral rights for the publications made accessible in the public portal are retained by the authors and/or other copyright owners and it is a condition of accessing publications that users recognise and abide by the legal requirements associated with these rights.

- Users may download and print one copy of any publication from the public portal for the purpose of private study or research.

- You may not further distribute the material or use it for any profit-making activity or commercial gain

- You may freely distribute the URL identifying the publication in the public portal 
Artificial lakes delay the migration of brown trout Salmo trutta smolts: a comparison of migratory behaviour in a stream and through an artificial lake

MICHAEL SCHWINN | HENRIK BAKTOFT | KIM AARESTRUP | ANDERS KOED

National Institute of Aquatic Resources, Technical University of Denmark, Vejlsøvej 39,

Silkeborg, Denmark

\section{Correspondence}

Anders Koed, National Institute of Aquatic Resources, Technical University of Denmark, Vejlsøvej 39, 8600 Silkeborg, Denmark

E-Mail: ak@aqua.dtu.dk

\section{Funding information}

This study was funded by the Danish Rod and Net Fishing Licence.

\section{ABSTRACT}

Juvenile salmonids experience high mortality when negotiating lentic waters during their downstream migration to the sea. The development of artificial lakes and wetlands in streams has become a widely used management tool to reduce nutrient load to coastal areas. Such wetlands may threaten anadromous populations. In this study we quantify net ground speed of downstream migrating brown trout Salmo trutta smolts in equally long stream and lake sections in a Danish lowland stream and artificial lake. This was done by passive integrated

This article has been accepted for publication in the Journal of Fish Biology and undergone full peer review but has not been through the copyediting, typesetting, pagination and proofreading process, which may lead to differences between this version and the Version of Record. Please cite this article as doi: 10.1111/jfb.13950 
transponder telemetry in 2016 and 2017. Mean net ground speed in the stream section was $36.58 \mathrm{~km} \mathrm{day}^{-1}$ and $0.8 \mathrm{~km} \mathrm{day}^{-1}$ in the lake section. This decrease of net ground speed through the lake may lead to prolonged exposure to predators and probably contributes to high mortalities threatening anadromous populations.

\section{KEYWORDS}

artificial lake, ground speed, lowland stream, Salmo trutta, salmonids, wetland

\section{1 | INTRODUCTION}

Juvenile anadromous brown trout Salmo trutta L. 1758 migrate to the sea after previous physiological and behavioural changes (smoltification; Folmar \& Dickhoff, 1980). The downstream migration phase is often associated with high mortalities due to predation by fish, mammals and birds. When the water current is reduced by river obstructions, such as weirs or artificial lakes, predation can cause extraordinary high mortality among downstream migrating salmonid smolts due to extended exposure time and high abundance of predators (Jepsen et al., 1998; Aarestrup et al., 1999; Olsson et al., 2001; Gauld et al., 2013; Schwinn et al., 2017a,b, 2018). This has become an increasing problem internationally, since a high number of artificial lakes and wetlands are created for their potential to reduce nutrient load to coastal areas and to improve habitats for birds and amphibians ( Arheimer \& Pers, 2017;

Hoffmann \& Baattrup-Pedersen, 2007; Vymazal, 2017).

In the late 1980s, wetlands and lakes were proposed as a nitrogen management tool (Mitsch, 1992; van der Valk \& Jolly, 1992). Since then, artificial lakes and wetlands have 
been created in Europe, North America, Asia and Australia (Vymazal, 2017) mainly to remove nutrients from agricultural drainage. This method is regarded as cost-effective (Fleischer et al., 2014) and, it is argued, has additional benefits besides nutrient removal, such as the creation of habitat for rare or endangered species, recreational opportunities and potential flood protection (van der Valk \& Jolly, 1992; Ebel \& Lowe, 2013).

The downstream migration of salmonids is believed to be partly passive displacement by the current (Thorpe et al., 1981), but studies have shown that $S$. trutta smolts position actively horizontally in the middle of the stream, where current velocity usually is highest (Svendsen et al., 2007). In the process of smoltification, salmonids lose their positive rheotactic behaviour and therefore current velocity mainly determines speed of river descent (Hansen \& Jonsson, 1985; Aarestrup et al., 2002; Jonsson \& Jonsson, 2011). When smolts must traverse lentic waters with no unidirectional currents, they must actively swim and search for the outlet and cannot depend on passive displacement.

The focus of this study is a comparison of migration speeds of descending S. trutta smolts in a small lowland stream and in an artificial lake, Egå Engsø. We investigate how discharge, water temperature, fork length $\left(L_{\mathrm{F}}\right)$ and time of day affect net ground speeds in the different sections over 2 years and discuss the results and potential consequences.

\section{2 | MATERIAL AND METHODS}

Handling and tagging of fish were conducted in accordance to the guidelines described in permission 2012-DY-2934-00007 from the Danish Experimental Animal Committee.

\subsection{Study area}


Egå Engsø is an artificial lake that was established in 2006 with the aim of reducing nutrient loads to Aarhus Bight. The lake is situated north of the city Aarhus in Denmark $\left(56^{\circ} 13^{\prime} \mathrm{N}\right.$, $10^{\circ} 13^{\prime} \mathrm{E}$; Figure 1). The shallow, eutrophic lake has a surface area of 90-112 ha, depending on stream discharge. The mean depth is $c .0 .8 \mathrm{~m}$ and the maximum depth $c .2 \mathrm{~m}$. The lake is fed by the Egå Stream, which originates from Lake Geding, c. $10 \mathrm{~km}$ upstream of Egå Engs $\varnothing$ and drains into Aarhus Bight c. $4.1 \mathrm{~km}$ downstream of the lake. Mean discharge into the lake was $0.52 \mathrm{~m}^{3} \mathrm{~s}^{-1}$ and water retention time in the lake was $c .20$ days in 2014. As well as $S$. trutta, other fish species occasionally observed during electrofishing surveys are three-spined stickleback Gasterosteus aculeatus L. 1758, pike Esox lucius L. 1758, perch Perca fluviatilis L. 1758, common roach Rutilus rutilus (L. 1758) and European eel Anguilla anguilla (L. 1758). Stocking plans include annual release of 5001 year-old hatchery-reared F1 offspring of wild $S$. trutta in mid-April. These fish are released $c .6 \mathrm{~km}$ upstream of the river mouth. Additionally, river mouth plantings of one-year-old S. trutta are conducted in Egå: 38001 year-old fish are released annually in the middle of April, $c .500 \mathrm{~m}$ upstream of the river mouth. In 2016, 21,600 fish were planted in the river mouth.

\section{2 | Experimental fish and PIT Telemetry}

In the periods 23 February-04 March 2016 and 27 February-09 March 2017, 821 and 841 wild S. trutta, respectively, were caught by electrofishing in a $c .4 \mathrm{~km}$ long stretch of the river Egå starting $100 \mathrm{~m}$ upstream of PIT antenna array 1 and a $500 \mathrm{~m}$ stretch of the tributary Koldkær bæk (Figure 1). Electrofishing was carried out using 500 V pulsed direct current, produced by a $2000 \mathrm{~W}$ generator (EU 20i, Honda; www.honda.co.jp). Prior to tagging, fork length $\left(L_{\mathrm{F}}, \pm 1 \mathrm{~mm}\right)$ was measured. Fish with a $L_{\mathrm{F}}$ of at least $110 \mathrm{~mm}$ were anaesthetised using benzocaine (20 $\mathrm{mg} \mathrm{l}^{-1}$ ) until operculum movement slowed significantly (4-5 min). PIT 
tags (Texas Instruments Type RI-TRP-RRHP, half duplex, $134 \mathrm{kHz}$, length $23 \mathrm{~mm}$, diameter $3.85 \mathrm{~mm}$, mass $0.6 \mathrm{~g}$; www.ti.com) were implanted into the body cavity through a 3-4 $\mathrm{mm}$ ventro-lateral incision made using a scalpel, anterior of the pelvic fins. Time for measuring and tagging was $<20 \mathrm{~s}$ per fish. Fish recovered (i.e., full equilibrium) and were released in the stream section where they were caught. Time from capture to release was typically between 20 and 60 minutes.

Two arrays of paired swim-through PIT antennas covering the entire streambed and channel depth, were installed in 2009 at the inlet (antenna array 2) and outlet (antenna array 3; c. $300 \mathrm{~m}$ upstream and c. $20 \mathrm{~m}$ downstream of the lake) to record fish entering and leaving the lake. In January 2016, a third array (antenna array 1) was installed c. 1500 m upstream of the lake, so the three arrays cover two similar distances (assuming linear distance in the lake). The PIT stations at the lake were powered by mains electricity and operated continuously during the study period. The array upstream in the river (antenna array 1) operated on two 12 V leisure batteries that were changed weekly. Uptime of this array was $100 \%$ during the study period in 2016 and $99.99 \%$ in 2017. This was validated using timed auto-emitter check tags that register in 30 min intervals on each individual antenna. Each antenna had a detection range of c. $0.5 \mathrm{~m}$ and operated with a $50 \mathrm{~ms}$ energisation, $50 \mathrm{~ms}$ receiving time, resulting in a rate of $c .10$ scans s$^{-1}$.

\section{3 | Environmental variables}

Water-level data were recorded at a station $250 \mathrm{~m}$ upstream of the inlet in 15 min intervals and used as a proxy for discharge. Water temperature data was logged in hourly intervals using a temperature logger (HOBO TidbiT 2; www.hobo.com) positioned at the PIT array located at the lake inlet. 


\subsection{Handling of data and statistical analysis}

\subsection{1 | Antenna efficiency}

(1)

27
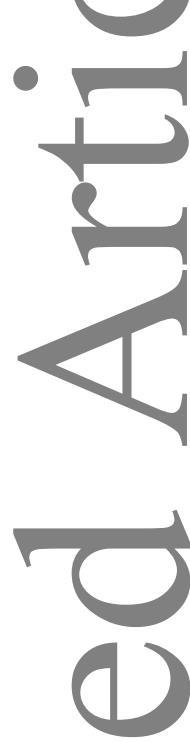
1

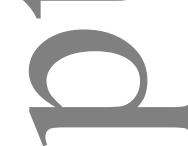

\subsubsection{Modelling net ground speed in the stream and in the lake}

Net ground speed was calculated by dividing the length of the migration route between the PIT arrays $(1.5 \mathrm{~km})$ by the difference in time between the first downstream registration and the last previous upstream registration (in the respective section). As the sizes of tagged fish were quite similar, distances in $\mathrm{m}$ or $\mathrm{km}$ were used instead of bodylengths.

Preliminary graphical analysis of the telemetry data indicated nonlinear patterns in the relationship between net ground speed and other variables. Therefore, data were analysed by using generalised additive models (GAM). Continuous predictor variables were checked for outliers and collinearity. (Zuur et al., 2010). Fish with $L_{\mathrm{F}}>190 \mathrm{~mm}$ were removed from the 
modelling dataset as they were underrepresented in the dataset $(n=23)$. A GAM using a $\gamma$ distribution with a log-link function was applied to analyse the response variable net ground speed using the predictors $L_{\mathrm{F}}$, water temperature $\left(T_{\mathrm{W}}\right)$, water level $\left(H_{\mathrm{W}}\right)$, time of day $\left(t_{24}\right)$ and year. The different sections stream and lake were added as an interaction term (section) with all variables to the model, so that different smoothers are calculated for the different sections (indicated by $\left.f_{\text {section }}()\right)$. Values of water temperature, water level and time of day were measured at the time of the registration at the first PIT array (antenna array 1) for the stream section and at the second PIT array (antenna array 2) for the lake section. This model was applied to a subset of fish that were passing the stream section within $12 \mathrm{~h}$, to exclude fish that apparently interrupted their migration after a first registration at the PIT array $1 ; n=$ 155). The final dataset used for this analysis consisted of 535 observations in the stream and 234 observations in the lake: Net ground speed, $V_{\mathrm{i}} \sim \gamma\left(\mu_{\mathrm{i}}, \tau\right) ; E\left(V_{\mathrm{i}}\right)=\mu_{\mathrm{i}}$ and var. $\left(V_{\mathrm{i}}\right)=\frac{\mu_{\mathrm{i}}{ }^{2}}{\tau}$ $\mu_{\mathrm{i}}^{2} \tau^{-1} ; \log \left(\pi_{\mathrm{i}}\right)=\alpha+f_{\text {section }}\left(L_{\mathrm{Fi}}\right)+f_{\text {section }}\left(H_{\mathrm{Wi}}\right)+f_{\text {section }}\left(t_{24 \mathrm{i}}\right)+f_{\text {section }}\left(T_{\mathrm{Wi}_{\mathrm{i}}}\right)+$ year $_{\mathrm{i}}: \operatorname{section}_{\mathrm{i}}+$ year $_{\mathrm{i}}+$ section $_{\mathrm{i}}$

Smoothing parameters were estimated by generalised cross validation (Wood, 2006).

For time of day, a cyclic penalized cubic regression spline was used to estimate a smoother, due to the circular nature of this variable. Smoothing basis dimensions were 9 for time of day and 10 for other variables in the model. Model selection aimed at the minimisation of the Akaike information criterion (AIC). The correlation between net ground speed in the two sections was assessed using Pearson's correlation. Statistical analysis was performed in R 3.5.1 (www.r-project.org). The R package mgcv 1.8-24 (Wood, 2011) was used for GAMs.

\section{3 | RESULTS}

\subsection{Antenna registrations and lake passage}


Out of the total of 1662 tagged fish, 709 (43\%) were registered at both PIT arrays upstream of the lake. The majority ( $n=550)$ of those passed the stream section within $12 \mathrm{~h}$. The remaining tagged fish were either not registered in the study period, only at a single array, or returned upstream after a registration at the inlet of the lake. Success rate of lake passage of the 709 fish registered at both upstream arrays was $34 \%(n=243)$ but varied between years (47\% in 2016 and $28 \%$ in 2017).

\section{2 | Antenna efficiency}

The efficiency of PIT array 1 was 93.3\% and 95.3\% in 2016 and 2017, respectively. The efficiency of PIT array 2 was $82.9 \%$ and $82.3 \%$ in 2016 and 2017, respectively.

\subsection{Net ground speed in the stream and lake}

Net ground speed differed substantially between the stream and the lake section. Mean net ground speed was $36.58 \mathrm{~km}^{-1}{ }^{-1}$ in the stream and $0.8 \mathrm{~km} \mathrm{day}^{-1}$ in the lake (Table 1 and

Figure 2). No association was found between net ground speed in the stream and in the lake (Pearson's correlation: $P>0.05, r=-0.07$ ), meaning that fish moving slowly in the stream did not necessarily move slowly in the lake, or vice versa.

\section{4 | Generalised additive model for net ground speed}

There was no problematic collinearity between continuous predictors in the model. The correlation between water temperature and water level was 0.5 . Single term deletion 
(including the interaction with section) from the full model revealed that the most important predictors for net ground speed were water level, year, temperature and time of day. $L_{\mathrm{F}}$ had less predictive power judged by the $\Delta$ AIC value. Table 2 shows AIC, $\triangle \mathrm{AIC}$ and degrees of freedom of the full model and a set of candidate models where one predictor was removed from the model.

In the next step, interactions between individual predictors and section were removed from the model not containing $L_{\mathrm{F}}$, to test whether effects differ between the stream and lake section. Resulting models were compared by AIC. After removal of individual interaction terms, one model had a $\triangle \mathrm{AIC}$ value $<6(\Delta \mathrm{AIC}=0.4)$ compared with the respective candidate models. Hence, this model was selected as final model $(\mathrm{AIC}=5071.8$, explained deviance $84.8 \%): \log \left(\pi_{\mathrm{i}}\right)=\alpha+f_{\text {section }}\left(H_{\mathrm{Wi}}\right)+f_{\text {section }}\left(T_{\mathrm{Wi}_{\mathrm{i}}}\right)+f\left(t_{24 \mathrm{i}}\right)+$ year $_{\mathrm{i}}:$ section $_{\mathrm{i}}$. The GAM model reveals section-specific effects of temperature and water level, whereas time of day appears to have a similar effect in both sections. In the stream, net ground speed was increased with increasing water level, at temperatures $5-9^{\circ} \mathrm{C}$ and during the hours around midnight (Figure 3). The analysed variables did not seem to affect net ground speed in the lake. $L_{\mathrm{F}}$ had a comparatively minor effect on net ground speed and was not retained in the model.

\section{4 | DISCUSSION}

Major difference in migration speed of S. trutta smolts were found between river and lake sections. The observed mean value of net ground speed in the stream of $36.58 \mathrm{~km} \mathrm{day}^{-1}$ was similar to values reported in other studies (Aarestrup et al.,, 2014; Serrano et al., 2009). In the lake, the fish were significantly slower, moving at a mean net ground speed of $0.8 \mathrm{~km} \mathrm{day}^{-1}$ (median, $0.47 \mathrm{~km} \mathrm{day}^{-1}$ ). Mean values of net ground speed in the same lake, calculated from data published by Schwinn et al. (2017a) varied between 0.24 and $0.3 \mathrm{~km} \mathrm{day}^{-1}$ in the years 
2009-2015. Net ground speed in a similar, albeit smaller artificial pond calculated from data published by Olsson et al. (2001) was 0.13 day $^{-1}$.

This difference in net ground speed was probably due to the different current regime in lotic and lentic environments. It has been shown that active positioning and swimming was relevant for downstream migration in riverine environments (Svendsen et al., 2007) and crucial to traverse lacustrine water bodies (Jepsen et al., 1998; Aarestrup et al., 1999; Olsson et al., 2001; Schwinn et al., 2017a,b). Yet, it is apparent that passive displacement plays a major role since downstream migration speed is largely dependent on current speed in streams and rivers, as shown in this study by the use of water level as proxy for discharge and elsewhere (Aarestrup et al., 2002). The current speed of the stream quickly fades in the lake and only comparatively low, wind-driven currents prevail in the lake. Accordingly, water level (flow) of the stream did not affect net ground speed in the lake and individual speed in the stream and in the lake was not associated; i.e., fish that were swimming fast in the stream did not necessarily negotiate the lake faster than individuals with a low net ground speed in the stream. Therefore, it seems that potential individual traits associated with migration speed in the stream have no predictive power for behaviour in the lake or vice versa. Wind-induced currents probably determine migration speed and direction in the lake to a large extent. Further research is needed to clarify the effects and interactions of these variables on smolt $S$. trutta swimming speed in lakes without unidirectional currents. A radio telemetry study in the same system revealed highly erratic patterns of smolts during lake passage (Schwinn et al. 2018). These included several back and forth movements between eastern and western regions of the lake, indicating a lack of orientation that delays or prevents successful lake passage. Similar reversed migration in lakes was found by Jepsen et al. $(1998,2000)$ and Aarestrup et al. (1999). 
Time of day and water temperature were less important for the explanation of net ground speed. Most fish negotiated the stream and lake sections during night, which is the typical pattern of downstream migrating salmonid smolts (Moore \& Potter, 1994; Moore et al., 1998; Aarestrup et al. 2002) and higher net ground speeds in the stream and in the lake were observed, when fish entered the respective sections during night time. However, only a few observations were available for daytime hours and the variation of net ground speed was high at any time. Most fish negotiated the stream at water temperatures of $5-9^{\circ} \mathrm{C}$. The model predicts highest net ground speeds at stream water temperatures between $c .5 .5$ and $7.4^{\circ} \mathrm{C}$ (Figure 3). Swimming performance of ectothermic fish increases with water temperature up to optimal values. Yet a high variation in net ground speed, even close to the thermal optimum suggests that other factors (probably discharge) play a more important role. Only a slight effect of increasing water temperature was observed on net ground speed within the lake. This could be due to increasing swimming endurance of $S$. trutta smolts at elevated temperatures up to $16.1{ }^{\circ} \mathrm{C}$, as reported by Ojanguren and Braña (2000). However, a temperature effect on the time needed to negotiate the lake was not found in a wider dataset from this study (Schwinn et al. 2017b). Therefore, observed temperature effects should be interpreted with care, since they are most likely masked by the strong effect of stream discharge. Furthermore, temperature effects may be of minor relevance considering the small spatial scale of the study area.

Since the effects of abiotic factors on net ground speed of fish that passed the stream section without long interruptions are of interest, 155 fish that remained for more than 12 hours in the stream section were excluded from the model. Yet, this exclusion did not change the general shape of the smoothing functions in the GAM and the median net ground speed of the fish that interrupted their migration was still higher in the stream $\left(0.8 \mathrm{~km} \mathrm{day}^{-1}\right)$ than in the lake $\left(0.5 \mathrm{~km} \mathrm{day}^{-1}\right)$. 
Net ground speed in the stream was higher in 2016 than in 2017. This result was probably caused by a general higher discharge during 2016 (Figure 3). Likewise, net ground speed in the lake was higher in 2016 than in 2017. Since no effect of stream flow or discharge on net ground speed in the lake was found in this study and in Schwinn et al. (2017b), other factors may explain the observed variation. Most likely, turbidity has a strong effect on net ground speed and on passage probability (Jepsen et al., 1998). For example, much higher mean net ground speeds of Salmo salar L. 1758 smolts $\left(3.5 \mathrm{~km} \mathrm{day}^{-1}\right.$; range $1.8-15.6 \mathrm{~km}$ day $^{-1}$ ) negotiating a large clear-watered lake in Newfoundland were observed (Bourgeois \& O’Connell, 1988).

We observed that the mean speed in the lake was only $2 \%$ of the value of riverine migration speed. This slow progression through the lake leads to prolonged exposure to predators such as pike E. lucius or birds, which are numerous in lacustrine environments. As a consequence, the survival of $S$. trutta smolts negotiating artificial lakes can be very low (Schwinn et al. 2017a, 2018). Further research is needed to fully understand how environmental factors control migration speed in lakes. The outcomes could possibly be used to improve the design of future artificial lakes. Thus, bypass solutions, where an alternative migration route is available, have been used and pass smolts efficiently without fully compromising nutrient removal (unpubl. data). Additionally, river restoration and enhancement programmes are recommended in system where the sea trout (migratory $S$. trutta) population is compromised due to the development of artificial lakes, as improved smolt production may counteract high smolt-loss.

\section{ACKNOWLEDGMENTS}


We wish to thank Jes Dolby and Jørgen Skole Mikkelsen for technical assistance and help with the fieldwork.

\section{REFERENCES}

Aarestrup, K., Baktoft, H., Koed, A., Del Villar-Guerra, D. \& Thorstad, E.B. (2014)

Comparison of the riverine and early marine migration behaviour and survival of wild and hatchery-reared sea trout Salmo trutta smolts. Marine Ecology Progress Series 496, $197-206$.

Aarestrup, K., Jepsen, N., Rasmussen, G. \& Økland, F. (1999) Movements of two strains of radio tagged Altlantic salmon, Salmo salar L., smolts through a reservoir. Fisheries Management and Ecology 6, 97-107.

Aarestrup, K., Nielsen, C. \& Koed, A. (2002) Net ground speed of downstream migrating radio-tagged Atlantic salmon (Salmo salar L.) and brown trout (Salmo trutta L.) smolts in relation to environmental factors. Hydrobiologia 483, 95-102.

Arheimer, B. \& Pers, B.C. (2017) Lessons learned? Effects of nutrient reductions from constructing wetlands in 1996-2006 across Sweden. Ecological Engineering 103, 404 414.

Bourgeois, C.E. \& O’Connell, M.F. (1988) Observations on the seaward migration of Atlantic salmon (Salmo salar L.) smolts through a large lake as determined by radiotelemetry and Carlin tagging studies. Canadian Journal of Zoology 66, 685-691.

Ebel, J.D. \& Lowe, W.H. (2013) Constructed ponds and small stream habitats: Hypothesized interactions and methods to minimize impacts. Journal of Water Resource \& Protection 5, 723-731.

Fleischer, S., Gustafson, A., Joelsson, A., Pansar, J. \& Stibe, L. (2014) Nitrogen Removal in Created Ponds. Ambio 23, 349-357. 
Folmar, L.C. \& Dickhoff, W.W. (1980) The Parr-Smolt transformation (Smoltification) and seawater adaption in salmonids. A review of selected literature. Aquaculture 21, 1-37.

Gauld, N.R., Campbell, R.N.B. \& Lucas, M.C. (2013) Reduced flow impacts salmonid smolt emigration in a river with low-head weirs. Science of the Total Environment 458-460, $435-443$.

Hansen, L.P. \& Jonsson, , B. (1985) Downstream migration of hatchery-reared smolts of Atlantic salmon (Salmo salar L.) in the River Imsa, Norway. Aquaculture 45, 237-248.

Hoar, W.S. (1988) The Physiology of smolting salmonids. In: The Physiology of Developing Fish, Vol. 11. Fish Physiology (eds W.S. Hoar \& D.J. Randall). Academic Press, pp $275-343$.

Hoffmann, C.C. \& Baattrup-Pedersen, A. (2007) Re-establishing freshwater wetlands in Denmark. Ecological Engineering 30, 157-166.

Jepsen, N., Aarestrup, K., Økland, F. \& Rasmussen, G. (1998) Survival of radio-tagged Atlantic salmon (Salmo salar L.) and trout (Salmo trutta L.) smolts passing a reservoir during seaward migration. Hydrobiologia 371/372, 347-353.

Jepsen, N., Pedersen, S. \& Thorstad, E.B. (2000) Behavioural interactions between prey (trout smolts) and predators (pike and pikeperch) in an impounded river. Regulated Rivers: Research \& Management 16, 189-198.

Jonsson, B. \& Jonsson, , N. (2011) Ecology of Atlantic Salmon and Brown Trout. Habitat as template for life histories. Springer, Dortrecht.

Mitsch, W.J. (1992) Landscape design and the role of created, restored and natural riparian wetlands in controlling nonpoint source pollution. Ecological Engineering 1, 27-47.

Moore, A., Ives, M., Scott, M. \& Bamber, S. (1998) The migratory behaviour of wild sea trout (Salmo trutta L.) smolts in the estuary of the River Conwy, North Wales. Aquaculture 168, 57-68. 
Moore, A. \& Potter, E.C.E. (1994) The movement of wild sea trout, Salmo trutta L., smolts through a river estuary. Fisheries Management and Ecology 1, 1-14.

Ojanguren, A.F. \& Braña, F. (2000) Thermal dependence of swimming endurance in juvenile brown trout. Journal of Fish Biology 56, 1342-1347.

Olsson, I.C., Greenberg, L.A. \& Eklöv, A.G. (2001) Effect of an artificial pond on migrating brown trout smolts. North American Journal of Fisheries Management 21, 498-506.

R Core Team (2017) R: A language and environment for statistical computing.

Schwinn, M., Aarestrup, K., Baktoft, H. \& Koed, A. (2017a) Survival of migrating Sea Trout (Salmo trutta) smolts during their passage of an artificial lake in a Danish lowland stream. River Research and Applications 33, 558-566.

Schwinn, M., Baktoft, H., Aarestrup, K. \& Koed, A. (2017b) A comparison of the survival and migration of wild and F1-hatchery-reared brown trout (Salmo trutta) smolts traversing an artificial lake. Fisheries Research 196, 47-55.

Schwinn, M., Baktoft, H., Aarestrup, K., Lucas, M.C. \& Koed, A. (2018) Telemetry observations of predation and migration behaviour of brown trout (Salmo trutta) smolts negotiating an artificial lake. River Research and Applications 1-9.

Serrano, I., Larsson, S. \& Eriksson, L.-O. (2009) Migration performance of wild and hatchery Sea Trout (Salmo trutta L.) smolts-Implications for compensatory hatchery programs. Fisheries Research 99, 210-215.

Svendsen, J.C., Eskesen, A.O., Aarestrup, K., Koed, A. \& Jordan, A.D. (2007) Evidence for non-random spatial positioning of migrating smolts (Salmonidae) in a small lowland stream. Freshwater Biology 52, 1147-1158.

Thorpe, J.E., Ross, L.G., Struthers, G. \& Watts, W. (1981) Tracking Atlantic salmon smolts, Salmo salar L., through Loch Voil, Scotland. Journal of Fish Biology 19, 519-537. Valk, A.G. van der \& Jolly, R.W. (1992) Recommendations for research to develop 
guidelines for the use of wetlands to control rural nonpoint source pollution. Ecological Engineering 1, 115-134.

Vymazal, J. (2017) The use of constructed wetlands for nitrogen removal from agricultural drainage: a review. Scientia Agriculturae Bohemica 48, 82-91.

Wood, S.N. (2011) Fast stable restricted maximum likelihood and marginal likelihood estimation of semiparametric generalised linear models. Journal of the Royal Statistical Society: Series B (Statistical Methodology) 73, 3-36.

Wood, S.N. (2006) Generalised additive models : An introduction with R. Chapman and Hall/CRC.

Zuur, A.F., Ieno, E.N. \& Elphick, C.S. (2010) A protocol for data exploration to avoid common statistical problems. Methods in Ecology and Evolution 1, 3-14. 
TABLE 1 Net ground speed and sample size in the stream and in the lake section

\section{Ground speed $\left(\mathrm{km} \mathrm{day}^{-1}\right)$}

\begin{tabular}{lccccccc} 
Group & Section & Minimum & Maximum & Mean & SD & Median & $\boldsymbol{n}$ \\
\hline \multirow{2}{*2016}{} & Stream & 0.02 & 83.10 & 39.26 & 29.42 & 43.52 & 232 \\
& Lake & 0.08 & 15.54 & 1.16 & 1.89 & 0.62 & 109 \\
\multirow{2}{*}{$\mathbf{2 0 1 7}$} & Stream & 0.02 & 80.6 & 35.28 & 26.11 & 37.70 & 477 \\
& Lake & 0.06 & 5.43 & 0.50 & 0.54 & 0.37 & 134 \\
\hline
\end{tabular}

TABLE 2 Variables of the full model and candidate models and respective AIC, $\Delta$ AIC and $d f$

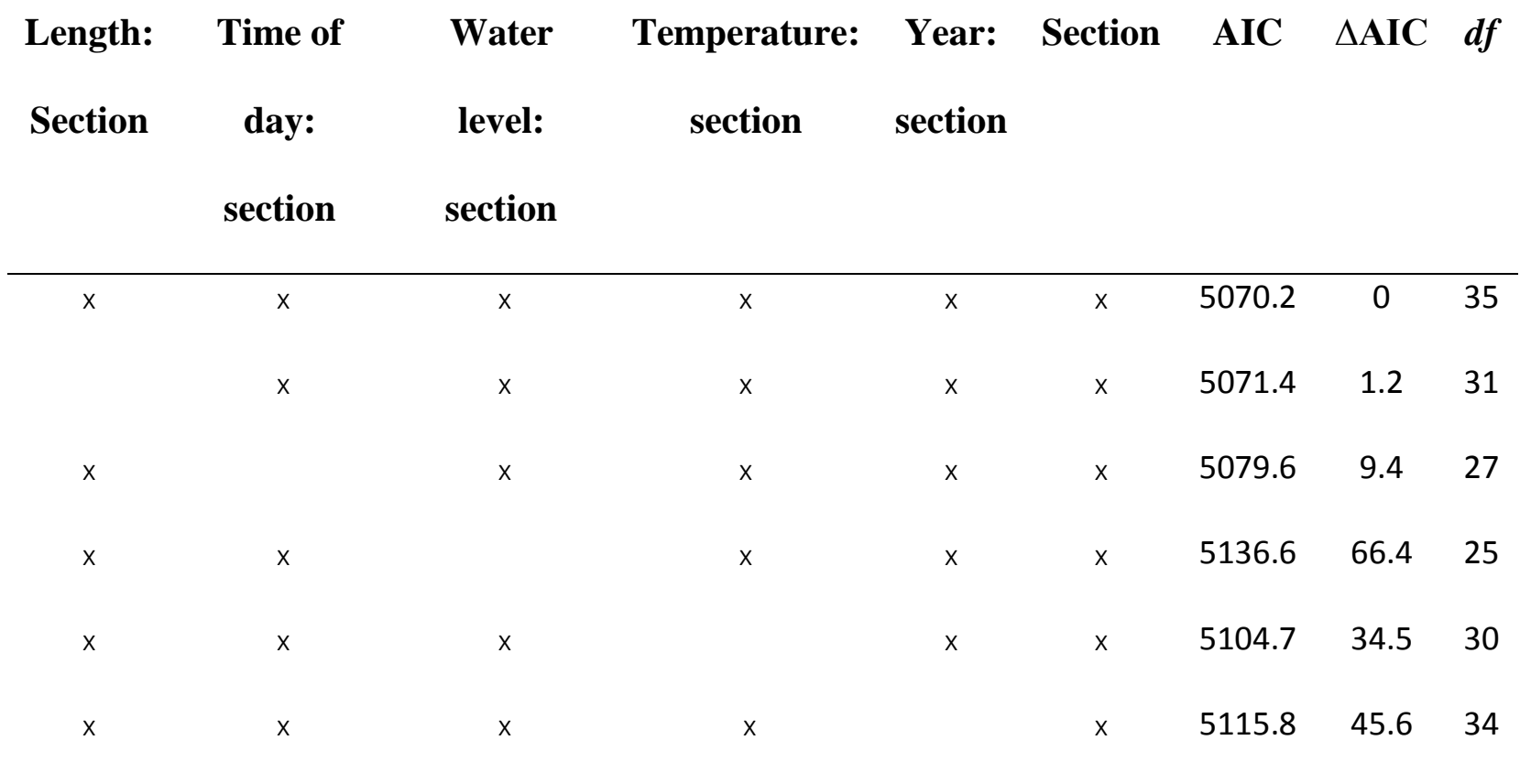


FIGURE 1: Map of the study area. Numbers in circles indicate positions of the PIT antenna arrays.

FIGURE 2. Net ground speed in the two sections of the study area. Raw data are jittered along the $x$-axis and surrounded by a bean indicating density by width. Horizontal lines indicate the median value.

FIGURE 3 Mean $( \pm 95 \%$ CI) net ground speed as a function of (a), (b) water level, (c), (d) water temperature and (e), (f) time of day in (a), (c), (e) the stream and (b), (d), (f) lake sections. Lines are predicted values, back-transformed to the original scale, obtained from a generalized additive model. Raw data points are added to the plot. 


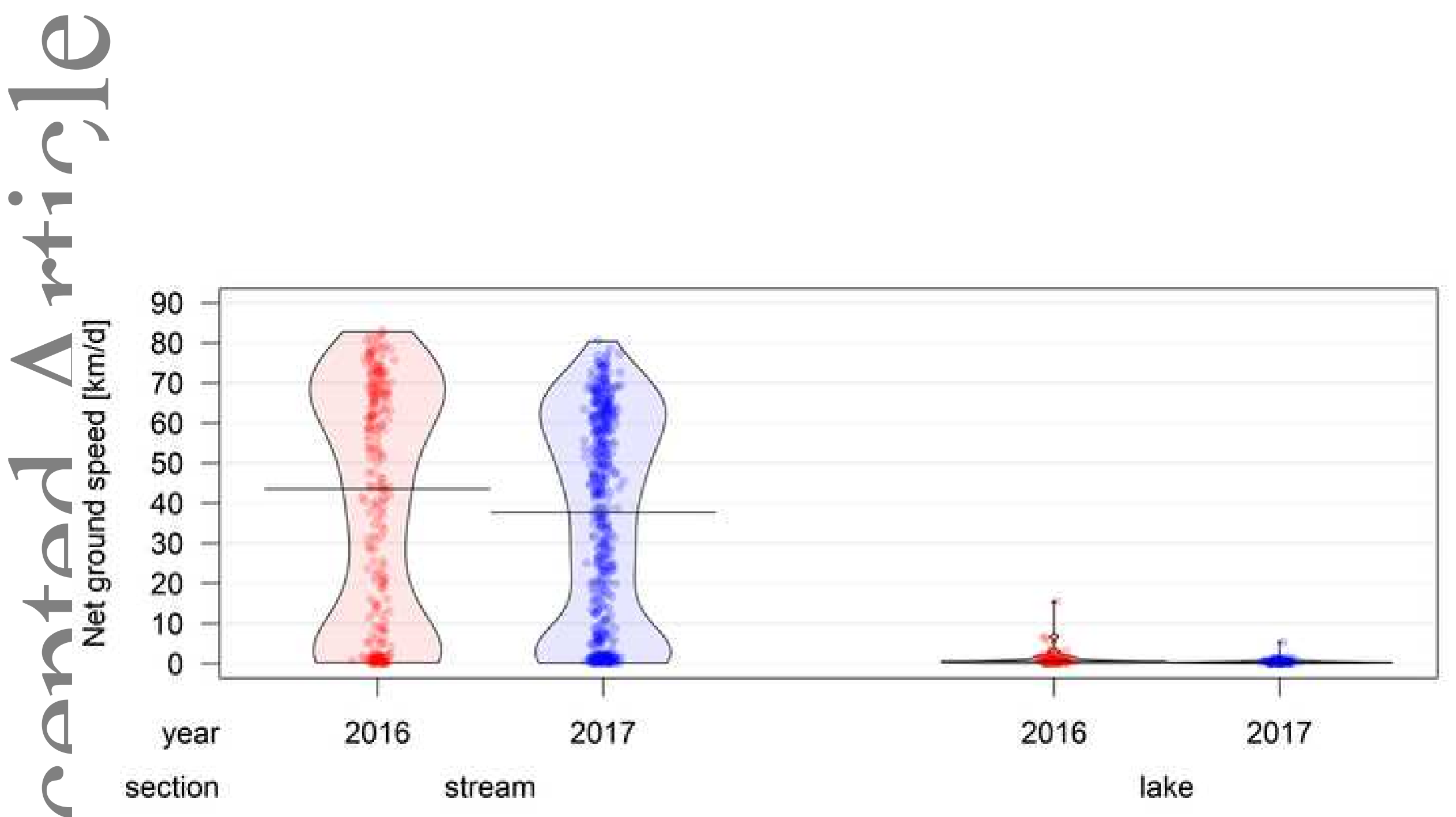

This article is protected by copyright. All rights reserved. 

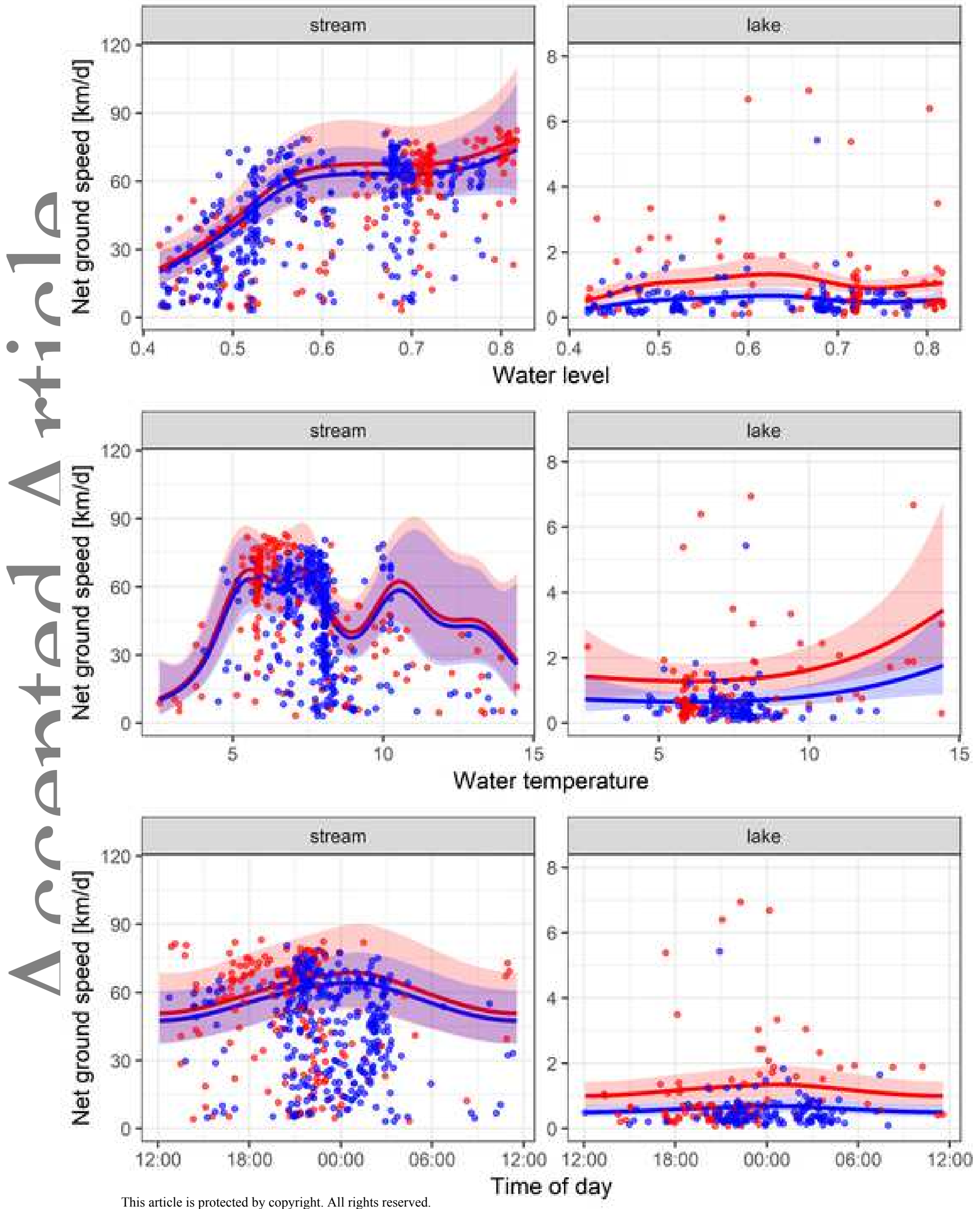

This article is protected by copyright. All rights reserved. 